\title{
SPATIAL CLUSTER UNTUK PENGELOMPOKKAN WILAYAH SETIAP PROVINSI DI INDONESIA BERDASARKAN KARAKTERISTIK KESENJANGAN EKONOMI
}

\author{
(SPATIAL CLUSTER FOR GROUPING REGIONS IN EVERY PROVINCE IN INDONESIA \\ BASED ON THE CHARACTERISTICS OF ECONOMIC DISPARITY)
}

\author{
Gideon Eka Dirgantara' ${ }^{1}$ Isriani Novianti ${ }^{2}$, Rokhana Dwi Bekti ${ }^{3}$ \\ ${ }^{1}$ Institut Sains \& Teknologi AKPRIND \\ ${ }^{2}$ Institut Sains \& Teknologi AKPRIND \\ Institut Sains \& Teknologi AKPRIND \\ Jalan Wulung Demangan 12 A Yogyakarta, \\ E-mail: gideondirgantara13@gmail.com
}

\begin{abstract}
ABSTRAK
Kesenjangan ekonomi antar wilayah merupakan fenomena global yang sering terjadi di negara berkembang, termasuk Indonesia. Kesenjangan ekonomi dapat dilihat dari pendapatan antar daerah yang tidak merata di setiap wilayah. Analisis yang dapat digunakan untuk mengelompokkan 34 provinsi di Indonesia berdasarkan karakteristik kesenjangan ekonomi salah satunya adalah metode spasial cluster. Penelitian ini bertujuan untuk mengetahui pengelompokan provinsi dengan metode SKATER (K'luster Analysis by Tree Edge Removal). Berdasarkan metode tersebut akan dibentuk 3 cluster dan 5 cluster untuk dibandingkan dan mendapatkan metode mana yang paling baik dengan analisis MANOVA. Hasil pengelompokan dari 3 cluster yang terbentuk dengan metode SKATER diperoleh hasil cluster 1 dengan 16 anggota provinsi. Cluster 2 dengan 2 anggota provinsi. Cluster 3 dengan 16 anggota provinsi. Hasil pengelompokan dari 5 cluster yang terbentuk dengan metode SKATER diperoleh hasil cluster 1 dengan 12 anggota provinsi. Cluster 2 dengan 1 anggota provinsi. Cluster 3 dengan 16 anggota provinsi. Cluster 4 dengan 1 anggota provinsi. Cluster 5 dengan 4 anggota provinsi. Dari analisis MANOVA didapatkan nilai Pillai's Trace untuk metode SKATER dengan 3 Cluster sebesar 1,177 dan SKATER dengan 5 Cluster sebesar 1,355. Hal ini dapat disimpulkan bahwa metode SKATER dengan 5 Cluster lebih baik dari pada 3 Cluster.
\end{abstract}

Kata kunci: Spasial Cluster, SKATER, Kesenjangan Ekonomi

\section{ABSTRACT}

Economic disparity between regions is a global phenomenon that often occurs in developing countries, including Indonesia. Economic disparities can be seen from uneven regional income in each region. The analysis can be used to classify 34 provinces in Indonesia based on the characteristics of economic inequality, one of which is the spatial cluster method. This study aims to determine the grouping of provinces using the SKATER (K'luster Analysis by Tree Edge Removal) method. Based on these methods 3 clusters and 5 clusters will be formed to compare and get the best method with MANOVA analysis. The results of grouping from 3 clusters formed by the SKATER method obtained the results of cluster 1 with 16 members of the province. Cluster 2 with 2 members of the province. Cluster 3 with 16 members of the province. The results of grouping from 5 clusters formed by the SKATER method obtained the results of cluster 1 with 12 members of the province. Cluster 2 with 1 member of the province. Cluster 3 with 16 members of the province. Cluster 4 with 1 member of the province. Cluster 5 with 4 members of the province. From the MANOVA analysis, the Pillai's Trace value for the SKATER method with 3 Clusters is 1,177 and SKATER with 5 Clusters is 1,355. It can be concluded that the SKATER method with 5 Clusters is better than 3 Clusters.

Keywords: Spatial Cluster, SKATER, Economic Disparity

\section{PENDAHULUAN}

Indonesia sebagai salah satu negara yang telah menyepakati penerapan tujuan pembangunan berkelanjutan (SDGs) berkomitmen untuk menyukseskan pelaksanaan SDGs melalui berbagai kegiatan dan telah mengambil langkah langkah strategis. Sustainable Development Goals adalah program dalam pembangunan berkelanjutan yang memuat 17 tujuan pembangunan utama yang 
harus dilaksanakan sebagai upaya membangun dunia lebih baik lagi, khususnya pada tujuan yang ke 10 yaitu untuk mengurangi angka ketimpangan dan kesenjangan terutama dalam negeri (BPS, 2016). Kesenjangan ekonomi antar wilayah atau daerah merupakan fenomena ekonomi global yang sering terjadi di negara berkembang, termasuk negara Indonesia. Kesenjangan ekonomi dapat dilihat dari pendapatan antar daerah yang tidak merata di setiap wilayah sehingga mempengaruhi tingkat kemiskinan suatu wilayah di Indonesia.

Indonesia memiliki presentase jumlah penduduk tertinggi sebesar 3,44\% pada peringkat 4 di dunia. Pada tahun 2017, Indonesia mengalami penurunan inflasi sebesar $9.8 \%$ dan mengalami tingkat jumlah pertumbuhan ekonomi sebesar 5,27 \% namun tingkat ketimpangan ekonomi di Indonesia masih cenderung tinggi. Pada tahun 2014 sampai 2018 indeks kesenjangan pendapatan di Indonesia selama lima tahun terakhir cenderung menurun. Nilai indeks tertinggi terjadi pada tahun 2014 sebesar 0,414 kemudian turun sampai pada nilai terendah di tahun 2018 sebesar 0,389. Artinya pada tahun 2018 kesenjangan pendapatan antar daerah paling rendah selama lima tahun terakhir (BPS, 2018).

Widianis (2015) menyatakan ada beberapa ukuran kesenjangan ekonomi yang dapat digunakan untuk mengukur tingkat kesenjangan ekonomi dalam distribusi pendapatan yaitu Indeks Rasio Gini, Indeks Williamson dan Indeks Theil. Ketiga indeks tersebut merupakan indikator tingkat kesenjangan ekonomi yang sering digunakan dalam mengukur tingkat kesenjangan ekonomi.

Berdasarkan latar belakang tersebut, untuk dapat mengetahui apakah terdapat pengaruh antar lokasi yang betetanggaan dalam pengelompokan setiap Provinsi, maka analisis yang dapat digunakan untuk mengelompokkan 34 provinsi di Indonesia berdasarkan karakteristik kesenjangan ekonomi salah satunya adalah metode spatial cluster. Penelitian yang dilakukan peneliti bertujuan untuk mengelompokkan setiap Provinsi yang ada di Indonesia berdasarkan kemiripan karakteristik kesenjangan ekonomi menggunakan variabel Indeks Rasio Gini, Indeks Theil dan Indeks Williamson dengan metode SKATER (K'luster Analysis by Tree Edge Removal). Metode ini bekerja menggunakan algoritma yang mentransformasi data-data kewilayahan menjadi grafik-grafik partisi. Metode ini melakukan partisi lokasi lokasi yang tidak bertetanggaan dan tidak memiliki kesamaan karakteristik. Metode SKATER menggunakan algoritma yang merupakan strategi untuk mengubah data kewilayahan menjadi grafik-grafik partisi. Metode SKATER baik untuk digunakan dalam melihat pola spasial apakah terdapat pengaruh atau tidak antar daerah yang bertetanggaan dalam proses untuk pengelompokan setiap provinsi, cluster yang baik adalah cluster yang memiliki nilai heterogenitas antar cluster yang besar dan nilai homogenitas dalam cluster yang kecil.

\section{METODE}

Desain penelitian yang digunakan dalam penelitian ini adalah desain pendekatan kuantitatif deskriptif. Teknik pengumpulan data untuk penelitian ini adalah menggunakan data sekunder, yang diperoleh dari Website BPS Indonesia BAPPENAS Indonesia yaitu data Indeks Rasio Gini, Indeks Theil T dan Indeks Williamson. Dari data tersebut akan dikelompokkan setiap wilayah dari 34 Provinsi di Indonesia berdasarkan karakteristik kesenjangan ekonomi menggunakan metode SPATIAL SKATER (K'luster Analysis by Tree Edge Removal).

Pengujian efek spasial dilakukan untuk mengetahui apakah terdapat efek lokasi pada model yang diteliti. Pengujian ini dilakukan dengan menggunakan Moran's I. Indeks Moran (Moran's I) merupakan metode yang paling banyak digunakan untuk menghitung autokorelasi spasial secara global. Uji Moran's I dapat dilakukan dengan hipotesis sebagai berikut : Hipotesis yang digunakan adalah $\mathrm{H}_{0}: \mathrm{I}=0$ (tidak ada autokorelasi antar lokasi), $\mathrm{H}_{1}: \mathrm{I} \neq 0$ (ada autokorelasi antar lokasi). Pengujian ini menggunakan Statistik uji (Lee dan Wong, 2001):

$$
Z_{\text {hitung }}=\frac{I-E(I)}{\sqrt{\operatorname{var}(I)}} \sim N(0,1) \text {. }
$$

Dengan $E(I)=$ expected value Moran's $I$ dan $\operatorname{Var}(I)=$ varians Moran's $I$. Pengambilan keputusan $H_{0}$ ditolak atau ada autokorelasi antar lokasi jika $\left|Z_{\text {hitung }}\right|>Z_{\alpha / 2}$. Nilai dari indeks $I$ 
adalah antara -1 dan 1 . Apabila $I>I_{0}$, data memiliki autokorelasi positif. Jika $I<I_{0}$, maka data memiliki autokorelasi negatif.

Metode SKATER menggunakan algoritma yang merupakan strategi untuk mengubah data kewilayahan menjadi grafik-grafik partisi. Metode SKATER dilakukan dengan dua langkah (Reis, et al, 2007). Langkah pertama adalah menentukan Minimum Spanning Tree (MST). MST tersebut menggambarkan grafik ketetanggaan antar lokasi berdasarkan variabel tertentu. Jika suatu kelompok lokasi $O$ dengan variabel $\left\{A_{1}, A_{2}, \ldots, A_{n}\right\}$. Setiap lokasi memiliki vektor variabel $\mathrm{x}=\left\{\mathrm{a}_{1}\right.$, $\left.a_{2}, \ldots, a_{n}\right\}$ dimana $a_{1}$ adalah semua kemungkinan nilai dari variabel $A_{1}$. Tipologi dari satu set data menunjukkan grafik koneksi $G=(V, L)$ dengan satu set simpul $V$ dan satu set edge $L$. Koneksi antar simpul $v_{1}$ dan $v_{j}$ terjadi apabila lokasi $i$ dan $j$ saling berdekatan (bertetanggaan). Jarak kedekatan tersebut diukur berdasarkan jarak Euclidean pada setiap jarak. Formula untuk jarak Euclidian untuk vector $x_{i}$ dan $x_{j}$ adalah $d_{i j}=d\left(x_{i}-x_{j}\right)$

$$
d\left(x_{i} x_{j}\right)=d_{i j}=\sqrt{\sum_{k=1}^{n}\left(x_{i k}-x_{j k}\right)^{2}}
$$

dimana:

$\mathrm{n} \quad=$ jumlah komponen vector $x$

$x_{i} x_{j} \quad=$ dua vector yang jaraknya akan dihitung

Langkah kedua, setelah terbentuk MST, SKATER melakukan partisi rekursif dari MST untuk mendapatkan pengelompokan. Hasil pengelompokan adalah adanya homogenitas variabel di dalam kelompok. Untuk membentuk partisi, dilakukan penghapusan ke-1 edge dari MST. Masing-masing akan menghasilkan kelompok yang berbentuk pohon. Partisi tersebut menghasilkan kelompok yang berbentuk pohon. Partisi tersebut menghasilkan grafik $G^{*}$ yang terdiri dari pohon $T_{1}, T_{2}, \ldots, T_{n}$. Dimana setiap pohon akan terkoneksi namun tidak memiliki simpul dan edge utama dengan pohon lain. Pemilihan edge adalah menggunakan jumlah kuadrat deviasi antar kelompok $\left(\mathrm{SSD}_{\mathrm{i}}\right)$, yaitu untuk meminimumkan

Rumus SSD yaitu, Reis et al. (2007):

$$
\mathrm{Q}(\Pi)=\sum_{\mathrm{l}=0}^{\mathrm{k}} \mathrm{SSDi}
$$

$$
S S D=\sum_{j=1}^{m} \sum_{i=1}^{n_{k}}\left(x_{i j}-\bar{x}_{j}\right)^{2}
$$

dimana:

$m$ : jumlah variabel

$n_{k}$ : jumlah kelompok koneksi

$x_{i j}$ : variabel dalam penelitian

$\bar{x}_{j}$ : rata-rata variabel dalam penelitian

Setelah terbentuk Cluster dilakukan pengujian MANOVA untuk menentukan Cluster terbaik. Manova dipilih karena variabel dependen saling berkorelasi.

$$
P=\sum_{i=1}^{p}\left(\frac{\lambda_{i}}{1+\lambda_{i}}\right)=\operatorname{tr} \lambda_{i}\left(1+\lambda_{i}\right)^{-1}
$$

$\Lambda^{*}=\operatorname{tr} \frac{|B|}{|B+W|}$, dimana $\boldsymbol{\Lambda}$ merupakan koefisien Pillai's Trace.

\section{HASIL DAN PEMBAHASAN}

Berdasarkan deskriptif hasil pemetaan, dapat disimpulkan bahwa dengan variabel gini rasio menunjukkan adanya kecenderungan karakteristik pola spasial untuk 34 Provinsi di Indonesia yaitu semakin ke timur maka tingkat indeks gini rasio provinsi semakin tinggi. Karakteristik tingkat 
indeksgini rasio juga dapat terlihat bahwa semakin ke barat cenderung memiliki tingkat indeks gini rasio provinsi yang rendah.

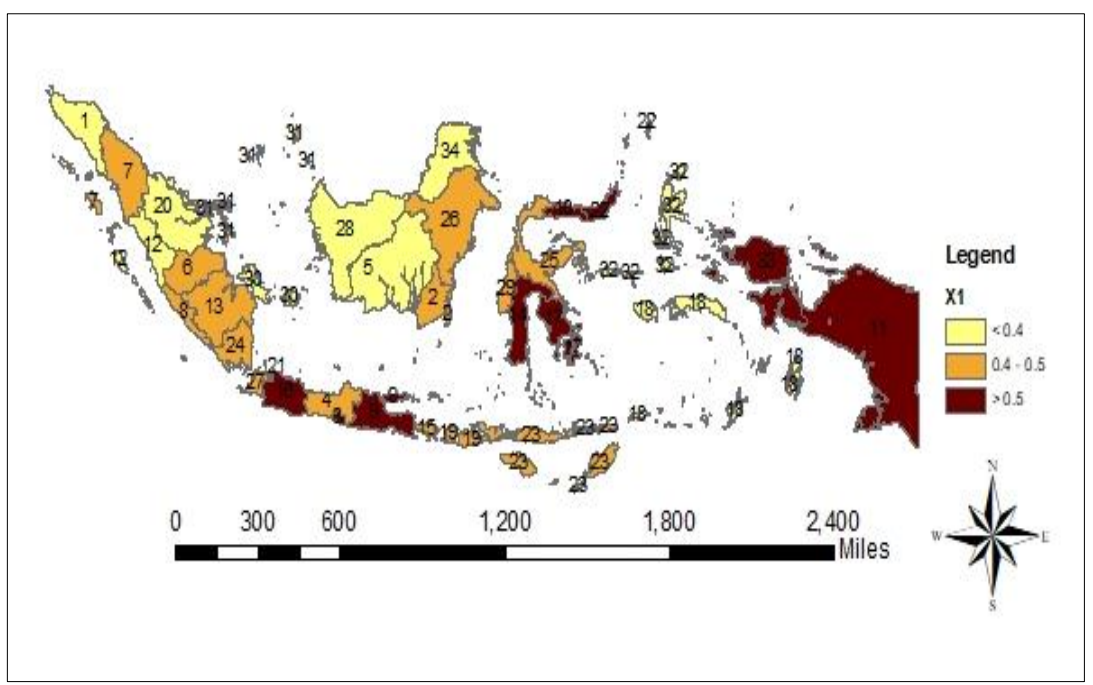

Gambar 1. Pola Spasial variabel Gini Rasio

Berdasarkan uraian diatas, dapat disimpulkan bahwa dengan variabel indeks theil-t menunjukkan adanya kecenderungan karakteristik pola spasial untuk 34 Provinsi di Indonesia yaitu semakin ke timur maka tingkat indeks theil-t provinsi semakin tinggi. Karakteristik tingkat indeks theil-t juga dapat terlihat bahwa semakin ke barat cenderung memiliki tingkat indeks theil-t provinsi yang rendah.

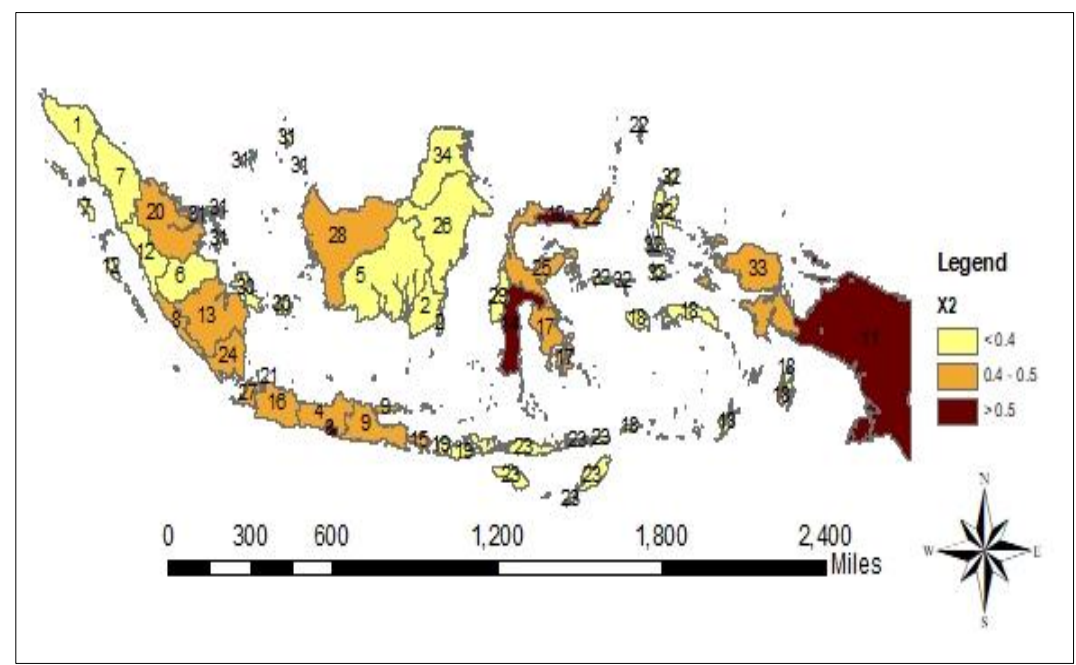

Gambar 2. Pola Spasial variabel Indeks Theil-T

Berdasarkan uraian diatas, disimpulkan bahwa variabel indeks williamson menunjukkan adanya kecenderungan karakteristik pola spasial untuk 34 Provinsi di Indonesia yaitu semakin ke timur maka tingkat indeks williamson provinsi semakin tinggi. Karakteristik tingkat indeks williamson juga dapat terlihat bahwa semakin ke barat cenderung memiliki tingkat indeks williamson provinsi yang rendah. 


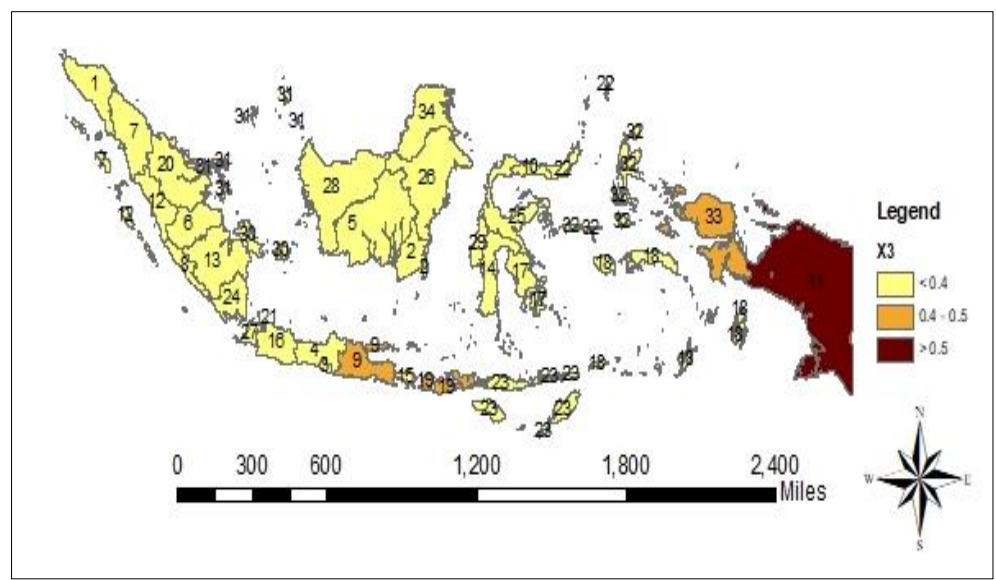

Gambar 3. Pola Spasial variabel Indeks Williamson

\section{Pengujian Efek Spasial (Uji Moran's I)}

Pengujian efek spasial dilakukan untuk mengetahui apakah terdapat efek lokasi pada model yang diteliti. Berdasarkan hasil uji Moran's I dengan menggunakan bantuan Software RStudio, diperoleh hasil bahwa variabel Gini rasio, Indeks Theil-T, dan Indeks Williamson dikatakan terdapat autokorelasi spasial. Hasil Uji Moran's I diperoleh:

Tabel 1. Morans I

\begin{tabular}{|c|c|c|c|}
\hline Variabel & $P$-value & Z-hitung & Keputusan \\
\hline $\mathrm{X}_{1}$ & 0,03036 & 2,165 & Tolak $\mathrm{H}_{\mathrm{O}}$ \\
\hline $\mathrm{X}_{2}$ & 0,00838 & 2,636 & Tolak $\mathrm{H}_{\mathrm{O}}$ \\
\hline $\mathrm{X}_{3}$ & $1,76 \times 10^{-5}$ & 4,292 & Tolak $\mathrm{H}_{\mathrm{O}}$ \\
\hline
\end{tabular}

\section{Analisis Cluster dengan Metode K'luster Analysis by Tree Edge Removal(SKATER)}

Langkah pertama adalah menentukan pembangkit Minimum Spanning Tree (MST). Penentuan ini dilakukan berdasarkan perbedaan-perbedaan pasang lokasi. Berikut hasil dari Minimum Spanning Tree (MST) berupa garis-garis koneksi antar 34 provinsi.

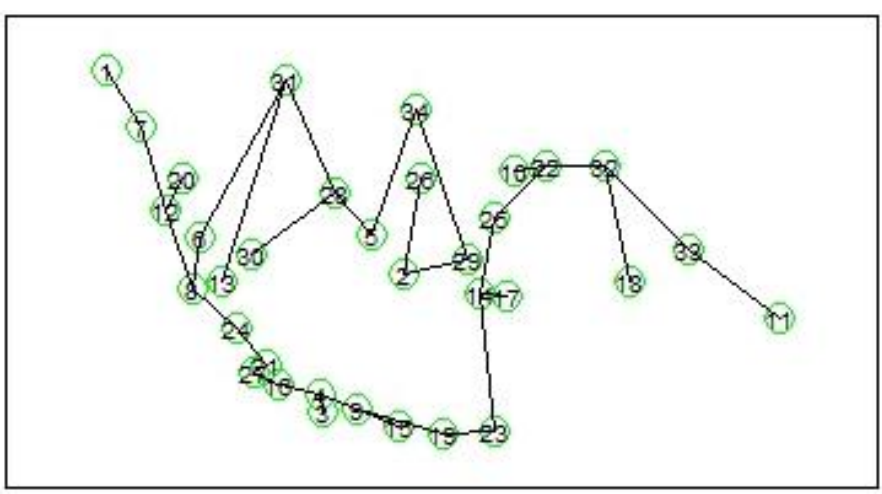

Gambar 4. Hasil MST

Tahap kedua pada analisis Minimum Spanning Tree (MST) adalah melakukan partisi dari Minimum Spanning Tree (MST). Partisi dilakukan dengan cara menghapus ke-1 edge dari Minimum Spanning Tree (MST). Penghapusan edge dilakukan dengan cara membandingkan nilai paling optimum dari beberapa kelompok partisi Minimum Spanning Tree (MST) yang terbentuk melalui iterasi. Sehingga didapatkan kelompok partisi Minimum Spanning Tree (MST) dengan nilai paling optimum melalui iterasi. Sehingga didapat beberapa kelompok partisi metode SKATER (K'luster Analysis by Tree Edge). Dari kelompok partisi tersebut, itulah yang menjadi kelompok cluster. Pengelompokan cluster dapat dilihat dari nilai SSD. Berikut hasil perhitungan dari partisi dari 434 
Minimum Spanning Tree(MST) yang menhasilkan 3 cluster dan 5 cluster yang disajikan pada gambar 5 dan gambar 6 sebagai berikut.

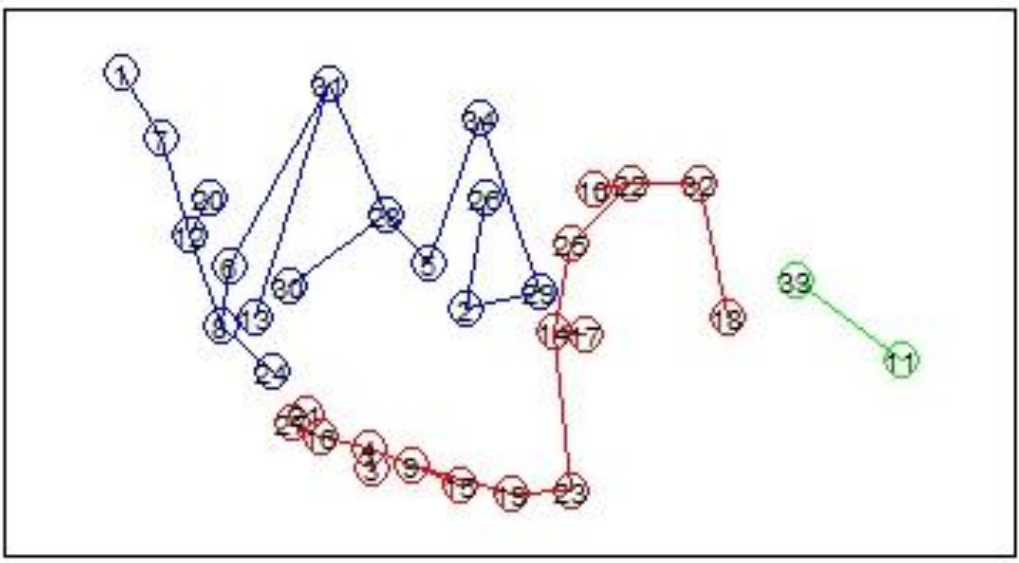

Gambar 5. Partisi MST 3 Cluster

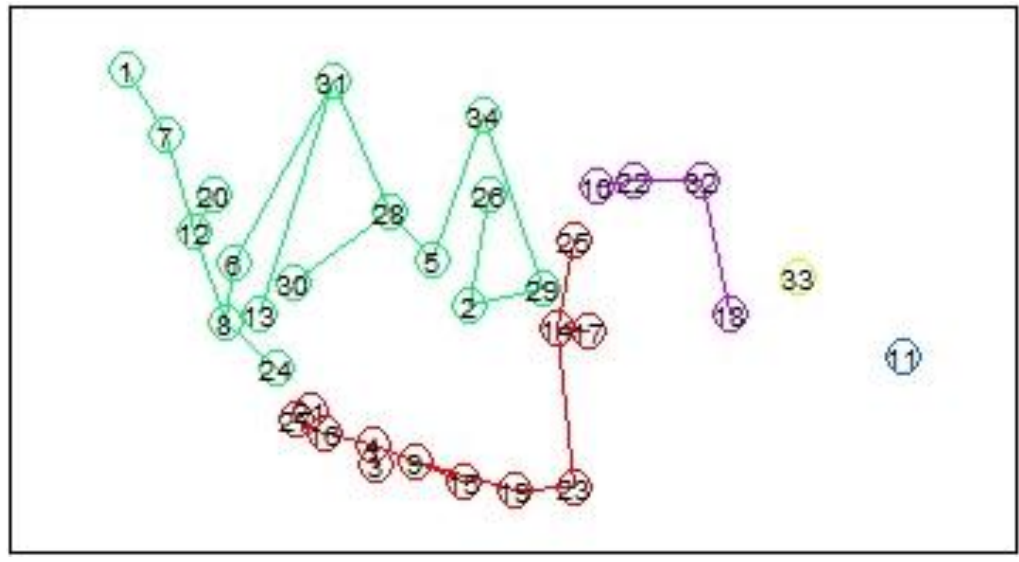

Gambar 6. Partisi MST 5 Cluster

Hasil yang diperoleh dari partisi MST yaitu terdiri dari 3 Cluster dengan jumlah untuk Cluster 1 sebanyak 16, Cluster 2 sebanyak 2 dan Cluster 3 sebanyak 16, sedangkan hasil yang diperoleh dari partisi MST yaitu terdiri dari 5 Cluster dengan jumlah untuk Cluster 1 sebanyak 16, Cluster 2 sebanyak 1, dan Cluster 3 sebanyak 16 dan Cluster 4 sebanyak 1, dengan anggota masing-masing cluster terlihat pada Tabel 2 dan Tabel 3.

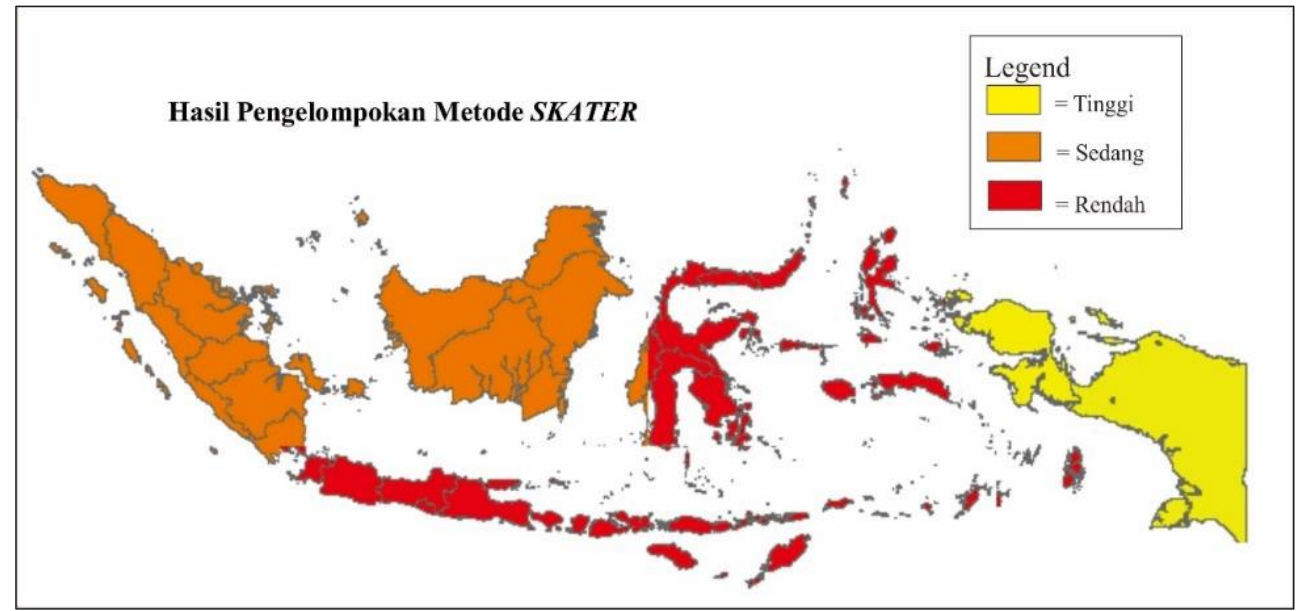

Gambar 5. Hasil Output dari 3 Cluster dengan Metode SKATER 
Tabel 2. Anggota dari 3 Cluster Metode SKATER

\begin{tabular}{ccl}
\hline Cluster & $\begin{array}{c}\text { Jumlah } \\
\text { Anggota }\end{array}$ & \multicolumn{1}{c}{ Anggota } \\
\hline $\mathbf{1}$ & 16 & $\begin{array}{l}\text { DKI Jakarta, Banten, Jawa Barat, Jawa Tengah, Sulawesi } \\
\text { Utara, Jawa Timur, Nusa Tenggara Barat, Maluku Utara, Nusa } \\
\text { Tenggara Timur, Sulawesi Tengah, Sulawesi Selatan, } \\
\text { Gorontalo, Maluku, Bali, DI Yogyakarta dan Sulawesi } \\
\text { Tenggara. }\end{array}$ \\
\hline $\mathbf{2}$ & 2 & \begin{tabular}{l} 
Papua Barat dan Papua \\
\hline $\mathbf{3}$
\end{tabular} \\
& 16 & $\begin{array}{l}\text { Lampung, Kepulauan Riau, Bengkulu, Kalimantan Barat, } \\
\text { Jambi, Kalimantan Tengah, Sumatra Barat, Sumatra Utara, } \\
\text { Kalimantan Utara, Sulawesi Barat, Kalimantan Selatan, } \\
\text { Sumatra Selatan, Kepulauan Bangka-Belitung, Riau, Aceh dan } \\
\text { Kalimantan Timur. }\end{array}$ \\
\hline
\end{tabular}

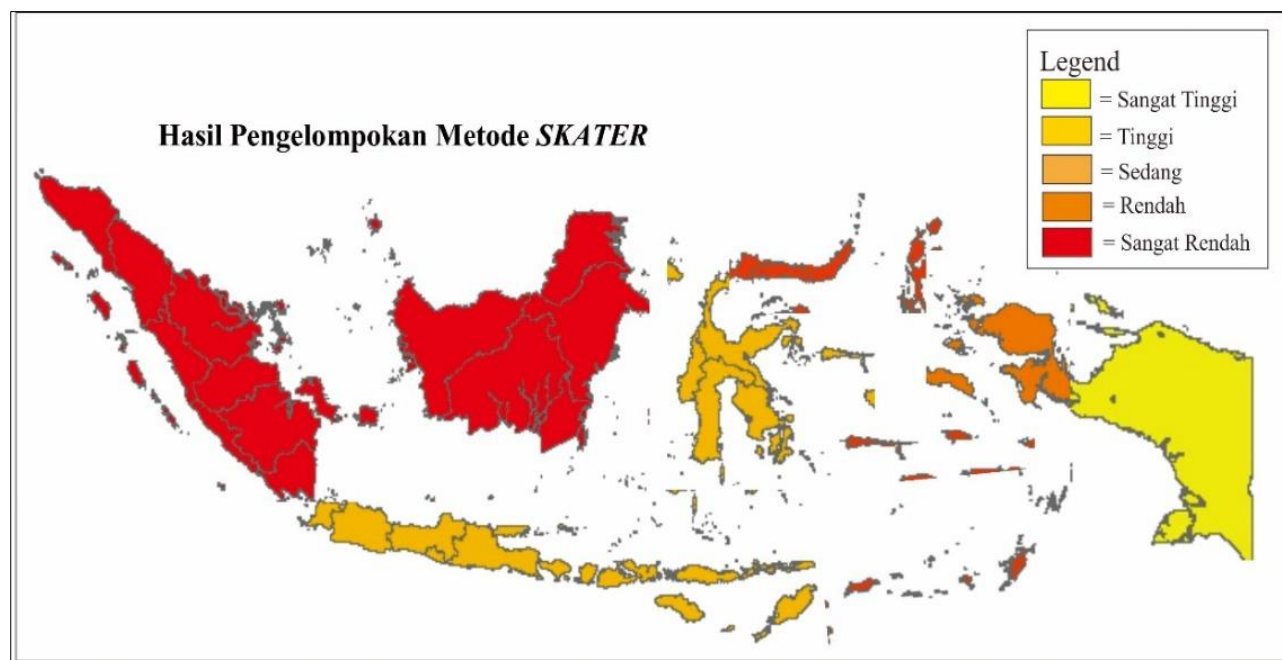

Gambar 6. Hasil Output dari 5 Cluster dengan Metode SKATER

Tabel 3. Anggota dari 5 Cluster Metode SKATER

\begin{tabular}{ccl} 
Cluster & $\begin{array}{c}\text { Jumlah } \\
\text { Anggota }\end{array}$ & \multicolumn{1}{c}{ Anggota } \\
\hline 1 & 12 & $\begin{array}{l}\text { Sulawesi Tengah, Sulawesi Selatan, Jawa Timur, Nusa } \\
\text { Tenggara Timur, Jawa Tengah, Banten, Nusa Tenggara } \\
\text { Barat, Jawa Barat, Bali, Sulawesi Tenggara, DI Yogyakarta } \\
\text { dan DKI Jakarta. }\end{array}$ \\
\hline 2 & 1 & Papua Barat \\
\hline 3 & 16 & $\begin{array}{l}\text { Lampung, Kepulauan Riau, Bengkulu, Kalimantan Barat, } \\
\text { Jambi, Kalimantan Tengah, Sumatra Barat, Sumatra Utara, } \\
\text { Kalimantan Utara, Sulawesi Barat, Kalimantan Selatan, } \\
\text { Sumatra Selatan, Riau, Kepulauan Bangka-Belitung, Aceh, } \\
\text { Kalimantan Timur. }\end{array}$ \\
\hline 4 & 1 & $\begin{array}{l}\text { Papua } \\
\text { Sulawesi Utara, Maluku Utara, Gorontalo dan Maluku. }\end{array}$ \\
\hline 4
\end{tabular}

\section{ANALISIS MANOVA}

Dalam penelitian ini, analisis MANOVA digunakan untuk membandingkan dua metode cluster yang bertujuan untuk mengetahui metode mana yang paling baik. 
Tabel 4. Hasil MANOVA

\begin{tabular}{ccc}
\hline Metode & Pillai's Trace & Nilai Signifikansi \\
\hline $\mathbf{3}$ Cluster & 1,177 & 0,000 \\
$\mathbf{5}$ Cluster & 1,355 & 0,000 \\
\hline
\end{tabular}

Dari nilai Pillai's Trace dapat dilihat bahwa dengan 3 Cluster sebesar 1,177 dan 5 Clustersebesar 1,355. Hal ini dapat disimpulkan bahwa pengelompokan dengan 5 Cluster lebih baik dari pada pengelompokan dengan 3 Cluster. Sehingga untuk mengelompokan wilayah 34 Provinsi di Indonesia berdasarkan karakteristik kesenjangan ekonomi baik menggunakan 5 Cluster SKATER. Pada Cluster 5 memiliki nilai heterogenitas antar cluster lebih besar dan nilai homogenitas dalam cluster lebih kecil dibandingkan Cluster 3, sehingga untuk mengelompokan 34 Provinsi berdasarkan karakteristik kesenjangan ekonomi di Indonesia lebih baik menggunakan 5 Cluster SKATER.

\section{KESIMPULAN}

Hasil pengelompokan wilayah 34 Provinsi di Indonesia dengan SKATER lebih baik menggunakan 5 Cluster karena heterogenitas antar cluster lebih besar dan nilai homogenitas dalam cluster lebih kecil dibandingkan Cluster 3. Hasil pemetaan dari metode SKATER menunjukkan bahwa provinsi di wilayah timur Indonesia seperti provinsi Papua cenderung memiliki tingkat kesenjangan tinggi karena adanya kesenjangan pembangunan infrastruktur yang tinggi dan jumlah penduduk yang berpendapat rendah masih banyak namun harga kebutuhan sangat mahal. Namun ketimpangan ekonomi di pulau Jawa, khususnya di provinsi DKI Jakarta, Jawa Barat dan DI Yogyakarta terjadinya karena banyaknya penduduk pendatang dan tidak diimbangi dengan terserapnya lapangan kerja yang memadai sehingga penduduknya cenderung heterogen dan tingkat konsumsi masyarakat bawah masih rendah dibanding konsumsi masyarakat menengah ke atas. Sedangkan di pulau Sumatera, Kalimantan dan Sulawesi mampu menjaga ketimpangan ekonomi antara pengeluaran dan pendapatan dan didukung dengan pembangunan infrastruktur yang baik.

\section{DAFTAR PUSTAKA}

Badan Pusat Statistik. (2017). Gini Ratio Provinsi September 2017. Badan Pusat Statistik. Jakarta.

Bekti R, D, dan Rachmawati Ro'fah. (2014). Spatial Cluster for Clustering the Influence Factor of Birth And Death Child In Bogor Regency, West Java. Departement of Statistic-School of Computer Science. Bina Nusantara University.

Bekti, R, D. (2015). Metode Spasial Skater Untuk Pengelompokan Lokasi Berdasarkan Fasilitas Air Bersih dan Sanitasi. Jurnal Matematika. Fakultas Sains Terapan, Institus Sains \& Teknologi AKPRIND. Yogyakarta.

Damarjati, Annisa Ganis. (2015). Analisis Faktor-Faktor yang Mempengaruhi Kesenjangan Pendapatan di Proponsi Jawa Tengah. Universitas Diponegoro. Semarang.

Ningsih, P. (2014). Pembentukan Zona Musim Kabupaten Ngawi dengan Metode SKATER. Institut Teknologi Sepuluh November. Surabaya.

Rizki Moh Rizal dan Setiawan Rulli Pratiwi, ST, M.Sc. (2015). Analisis Cluster Dalam Mengidentifikasi Karakteristik Timbulan Sampah Rumah Tangga di Perkotaan Kabupaten Jember. Jurnal Perencanaan Wilayah dan Kota. Fakultas teknik Sipil dan Perencanaa. ITS. Surabaya.

Santoso, S. (2014). Statistik Multivariat. PT Gramedia. Jakarta.

Sadahiro, Y., (2016). Spatial Analysis using GIS. Associate professor of the Department of Urban, Engineering University of Tokyo. Japan.

Widianis,Dwi. (2015). Analisis Kesenjangan Antar Kabupaten/Kota di Nusa Tenggara Timur Tahun 2007-2010. Institut Pertanian Bogor. Bogor.

Heryanah. (2017). Kesenjangan Pendapatan di Indonesia: Studi Empiris Berdasarkan SUSENAS 2017. Jurnal BAPPENAS Vol.10 No.2 Tahun 2017. Jakarta. 